$\left[\begin{array}{lll}\text { THE } & \text { 告 } \\ \text { JOURNA } & \text { 化 } & \text { 学 } \\ \text { HYGIENIC CHEMISTRY } \\ 22(6) & 370-374 & (1976)\end{array}\right]$

竹の皮に塗布された第四級アンモニウム塩の検出と定量

\author{
金田吉男, 慶田雅洋 \\ 国立衛生試験所 大阪支所 ${ }^{11}$
}

\title{
Detection and Determination of Quaternary Ammonium Compounds applied on Bamboo Sheath
}

\author{
Yoshio KANEDA and MASAHIRo IWAIDA \\ National Institute of Hygienic Sciences, Osaka Branch ${ }^{1)}$
}

(Received May 1, 1976)

\begin{abstract}
Quaternary ammonium chloride is being used increasingly to give a glossy appearance on the surface of bamboo sheath, which is used as a food wrapping. Extraction of this quaternary ammonium chloride is rather difficult because it may have combined with some constituents of the bamboo sheath. A method was therefore devised to isolate and determine the quaternary ammonium chloride. Bamboo sheath is cut into small pieces, heated with $0.1 \mathrm{~N} \mathrm{HCl}$ for $30 \mathrm{~min}$, and then the acidic solution is extracted with two $30 \mathrm{ml}$ portions of ethanol. Ethanol is steam distilled from this extract and quaternary ammonium chloride in the residual aqueous solution is determined by the Bromophenol Blue method, the amount being expressed as mole of benzethonium chloride.
\end{abstract}

\section{実 験 の 部}

第四級アンモニウム（以下 $Q A C$ と称す）は殺菌剤と して広く食品工業の各分野で使用されている．最近にな って，竹の度にQACを叙布し色つやを增したものが輸 入されていることがわかった。

竹の皮は食品を直接刨装するのに用いるので，その表 面にあるQAC は食品を通じて人体传取されることす あると考えられる，そこで QAC の検出掠よび定量法に ついて検討した。

分析操作の3 行程, すなわら抽出，クリンアップ拉よ び定量のらら，抽出がもっとも困難であると考兄られた ので，本報ではそ礼に重点を置いて検討した，抽出が難 しいのは，QAC の水溶液を竹の皮に塗布すると，表面 の小孔を通じて内部にも漫透するためと考学られる。

抽出は QAC 全般の溶剤として知られているエタノー ルを用いて，また定量はブロムフェノールブルー(BPB) -QAC 複塩をジクロルエタン (DE) 溶液中で比色定量す る方法2で行なった。
1. 試薬 Benzethonium chloride(以下 B と称す, 東京化成製)， hexadecyltrimethylammonium chloride （以下 $\mathrm{H}$ と称す，東京化成製）特上び Zephiramine（以 下 Z と称す，同仁薬化学秏）使用，1，2-dichloroethane （以下 DE之称吉, 和光純薬製) 拉よび bromophenol blue（以下 BPB と称寸, 片山化学製) を使用.

\section{2. 機器 日立 139 型 UV-VIS 分光光度計.}

3. 竹の皮に塗布された QAC の定呾法（スクリーニ ングテスト) 竹の皮 $(10 \times 10 \mathrm{~cm})$ を細切 $(1 \times 1 \mathrm{~cm})$ して $50 \mathrm{ml}$ の共せんフラスコにとり，0.1 $\mathrm{N}$ 塩酸 $10 \mathrm{ml}$ を添加, 還流冷却器を付して30分間弱い直火で加熱した のち室温まで放冷し，ついでフラスコ内容物をエタノ一 ル $30 \mathrm{ml}$ ずつで 2 回振と5抽出し, さらに $60 \mathrm{ml}$ の水で 洗い，抽出液および洗液を合わせて $500 \mathrm{ml}$ の蒸留フラ スコに移し, 水蒸気蒸留を行なって留液 $160 \mathrm{ml}$ をと, 留液は廃棄する。蒸留フラスコ内の残留液を室温まで放 冷後, $200 \mathrm{ml}$ のメスフラスコに移し定容として検液とす

1) Location : No. 6, Hoenzaka-cho, Higashi-ku, Osaka, 540,Japan（大阪市東区法円坂町 6).

2) Association of Official Analytical Chemists, "Official Methods of Analysis of The A.O.A.C.", 12 th ed., $1975,20.084$. 
る。

検液 $50 \mathrm{ml}$ を分液口ート $(300 \mathrm{ml})$ に正確にとり， $\mathrm{BPB}$ 溶液 $(0.04 \rightarrow 100) 3 \mathrm{ml}$, 塩酸 $(1 \rightarrow 2) 2 \mathrm{ml}$ おょび $\mathrm{DE} 50 \mathrm{ml}$ を加党て 4 分間振とうし，分離した下層(DE) を第 2 の分液口-ト (100 ml) 飞移し，1\%炭酸ナトリ ウム溶液 $10 \mathrm{ml}$ を加えて 4 分間振とうし，下層 (DE) に 無水硫酸ナトリウムを加克て 30 分間放置したのら，その 呈色を波長 $610 \mathrm{~nm}$ で比色する。

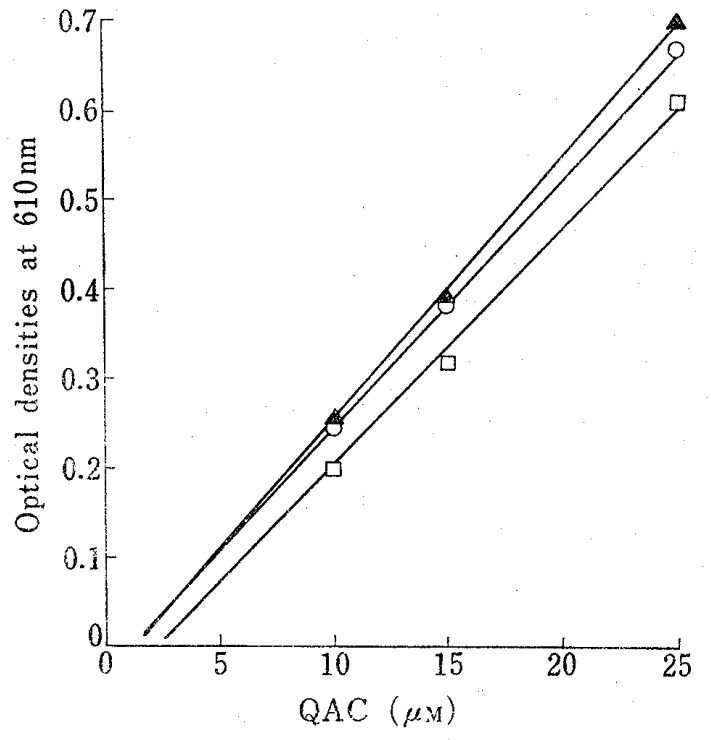

Fig. 1. Calibration Curves for QAC

B : benzethonium chloride

$\mathrm{H}$ : hexadecyltrimethylammonium chloride $\mathrm{Z}:$ Zephiramine

$\mathrm{O}-\mathrm{O}: \mathrm{B}\left(\mu_{\mathrm{M}}\right)=35.27(\mathrm{OD})_{610}+1.56$

$\square-\square: \mathrm{H}(\mu \mathrm{M})=36.55(\mathrm{OD})_{610}+3.03$

$A-Z\left(\mu_{M}\right)=33.69(O D)_{610}+1.75$
別に Bの0，2.5，5.0，10.0，15.0，20.0 および 25.0 $\mu_{\mathrm{M}}$ 溶液各 $50 \mathrm{ml}$ ずつを分液口ートにとり，以下検液と 同様の操作を行って検量線を作製し，これを用いて検液 中の QAC 含量を定量する。この方法での最低検出限度 はBとして $0.4 \mu \mathrm{mole}(224 \mu \mathrm{g}) /\left(\right.$ 竹の皮 $200 \mathrm{~cm}^{2}$, 表と 裹), 検液 $200 \mathrm{ml}$ 全量用いて操作するとさ $0.1 \mu \mathrm{mole}$ $(44.8 \mu \mathrm{g}) / 200 \mathrm{~cm}^{2}$ である。

\section{結果 と存察}

\section{QAC の検量線}

A.O.A.C. 法 ${ }^{2}$ に従って操作した B，H 扩よびZ(Chart 1 参照) の検量線を Fig.1 に示市.

3つの QAC の検量線のかたむきは活ぼ等しくぬなた それらを用いた等モル濃度の検量值の間にも有意差はな いと又られる。すなわち，Table I に示すように，3つ の検量線でもっとも吸光度の差異の大きい濃度 $(25 \mu \mathrm{M})$ に括计る吸光度（各3試行）の平均值拉よび偏差 2 乗和 を用いて $t$-test 検定を行なったところ，B，H执よび $Z$ の吸光度の間には有意差が認められなかった。

一方，この吸光度とQAC 側鎖鎖長との間には相関関 係はなく, 3)また微㫪のQACを同定するにはかなり複雑 な手法4を要する。

このように個々のQACを同定したのち定量すること は困難でありまた 3 種の異なる QAC のモル表示検量 線の間には有意差そ認めなかったので，竹の皮塗布さ れた未知の QAC の定量には容易に高純度標品が壳られ るBの検䁪線を朋いて行ない，その量はBとして表示す ることにした。な竹竹の皮に用いられるのは benzalkonium chloride $\left[\mathrm{C}_{6} \mathrm{H}_{5} \mathrm{CH}_{2} \mathrm{~N}\left(\mathrm{CH}_{3}\right)_{2} \mathrm{R}\right] \mathrm{Cl}, \mathrm{R}=\mathrm{C}_{8} \mathrm{H}_{17}-\mathrm{C}_{18}$ $\mathrm{H}_{37}$ であるといわれている。<smiles>CC(C)(C)CC(C)(C)c1ccc(OCCOCC[N+](C)(C)Cc2ccccc2)cc1</smiles>
bonzethonium chloride (mol. wt., 448.09)

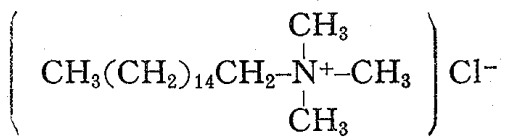

hexadecyltrimethylammonium chloride (mol. wt., 320.01)

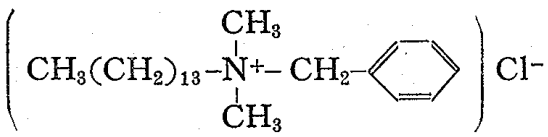

Zephiramine (mol. wt., 368.04)

Chart 1. Chemical Structure of Three Quaternary Compounds

3) J. B. Wilson, J. Assoc. Offic. Agr. Chem., 29, 311 (1946).

4) T. Kojima, H. Oka, Kogyo Kagaku Kai-shi, 71, 86 (1968) ; L. D. Metcalfe, J. Am. Oil Chemists' Soc., 40, 25 (1963). 
TABLE I. Examination of Significance among the Three QAC's Optical Densities at $25 \mu \mathrm{M}$

\begin{tabular}{clllll}
\hline Sample & $\mathrm{OD}_{610}{ }^{a}$ & $\overbrace{\text { Between }}^{\text {Sum of }}$ & $t_{0}$ & Evaluation $^{b)}$ \\
\hline $\mathrm{B}$ & 0.653 & 0.0038 & $\mathrm{~B}$ and $\mathrm{H}$ & 1.234 & not significant \\
$\mathrm{H}$ & 0.596 & 0.009 & $\mathrm{~B}$ and $\mathrm{Z}$ & 1.634 & not significant \\
$\mathrm{Z}$ & 0.694 & 0 & $\mathrm{H}$ and $\mathrm{Z}$ & 2.532 & not significant \\
\hline
\end{tabular}

a) mean value of three trials

b) $t$ (f, 0.05), $n_{\mathrm{B}}=n_{\mathrm{H}}=n \mathrm{Z}=3, f=3+3-2=4$, so that $t(4,0.05)=2.776$

\section{2. エタノールの留去}

抽出に用いたエタノールの存在は QAC の界面活性剂 としての性質に影響する ${ }^{5}$ ので， BPB-QAC 複塩形成に も何らかの影響を与光ると推定される，そこでェタノー ル $(0.1-10 \%)$ を含むBの $25 \mu_{\mathrm{M}}$ 溶液を調製し，前項に 準じて発色させたときの吸光度とエタノール濃度との関 係をFig. 2 に示す.エタノール含量 $0 \%$ のきの吸光度 を100とすると，エタノール0.1\%(95.5)，0.2\%(92.5)， 0.5\%（88.7） と吸光度は潮減し，10\%（66.9）飞いた る。このように共存ェタノールはB の定量值に負の妨害 を与光ここがわかったので，検液からエタノールを除 去する力法を検討した。

はじめに，沸とう水浴中で検液を半量まで濃縮するこ とを試みた。 B $(3 \mu$ mole, $60 \mathrm{ml})$ に $60 \mathrm{ml}$ の土タノー ルを加え, 約 $60 \mathrm{ml}$ 秀で濃縮したのちメスフラスュ(200 $\mathrm{ml}$ )に移して水で定容とした。このときの回収率はTable

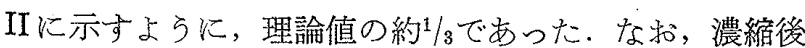
の器壁に若干の結晶よう物質の沈着およびアルコール臭 の残存をみた。

ついで 14 量までの濃縮を試み，器壁は熱水で洗浄，濃 縮液と洗液を合わせて $200 \mathrm{ml}$ としたものに括外る回収 率は理論值の $1 / 2$, 検液にはな䅂アルコール臭の残存があ った。

この実験に猢子る低い回収率の原因の 1 つはェタノー ルによる呈色妨害 (Fig. 2参照) であり，いまひとつは 沈着した QAC が少量の熱湯では充分に溶出しないため と考えられる。

そこで水にやや難溶な QAC を熱水中に溶解保持させ るとともに，エタノ一ルを注㜔完に留去できる水蒸気 蒸留法の利用を検討した。すなわち，Bの $3 \mu$ mole を 含を $60 \mathrm{ml}$ をとり，これにェタノール $60 \mathrm{ml}$ を加えた混 液を水蒸気蒸留化付し $160 \mathrm{ml}$ の留出液をとり, フラス コ中の残留液について調べたところ，添ぼ 100\%の回収 率がえられた。したがって，エタノ一ル留去は水蒸気蒸
$\mathrm{T}_{\mathrm{ABLE}}$ II. Recoveries of $\mathrm{B}^{a}$ ) ( $3 \mu$ mole) after Removal of EtOH by Three Different Methods

\begin{tabular}{lc}
\hline \hline Removal method & Recovery (\%) \\
\hline $\begin{array}{l}\text { Condensed to } 60 \mathrm{ml} \\
\text { in boiling water bath } \\
\text { Condensed to } 30 \mathrm{ml} \\
\text { in boiling water bath } \\
\begin{array}{l}\text { Combine the concentrate } \\
\text { and rinsing (hot water) }\end{array}\end{array}$ & 36.0 \\
Steam distillation & 44.6 \\
\hline
\end{tabular}

a) $\mathrm{EtOH}(60 \mathrm{ml})$ was added to water solution of benzethonium chloride $(60 \mathrm{ml})$.

b) distilled off $160 \mathrm{ml}$ of EtOH-water mixture

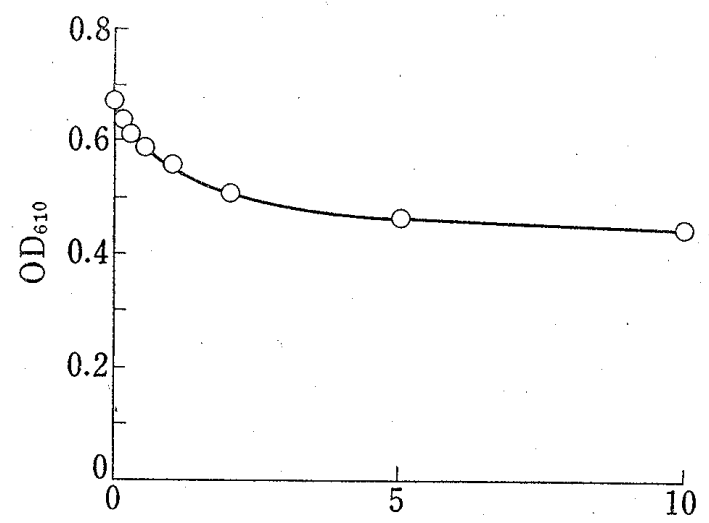

EtOH content $(v / v, \%)$ in benzethonium chloride solution $(25 \mu \mathrm{H})$

Fig. 2. Effects of EtOH Content on Color Development of BPB-QAC Complex

留法で行うこととした。

\section{3. 竹の皮からの QAC の抽出}

竹の度 $(10 \times 10 \mathrm{~cm})$ の裏側江 $\mathrm{B}(3 \mu$ mole, $1344 \mu \mathrm{g})$ の水溶液をのせ，窒温で風乾したのち $1 \times 1 \mathrm{~cm}$ に細切し て検討試料とした。

この試料をエタノール $(30 \mathrm{ml})$ 中に 24 たは48時間漫 漬したのち10分間振とら抽出し, つついて $30 \mathrm{ml}$ のェタ

5）觹田耕三, “溶液と溶解度,”丸善, 東京, 1966, p. 167. 


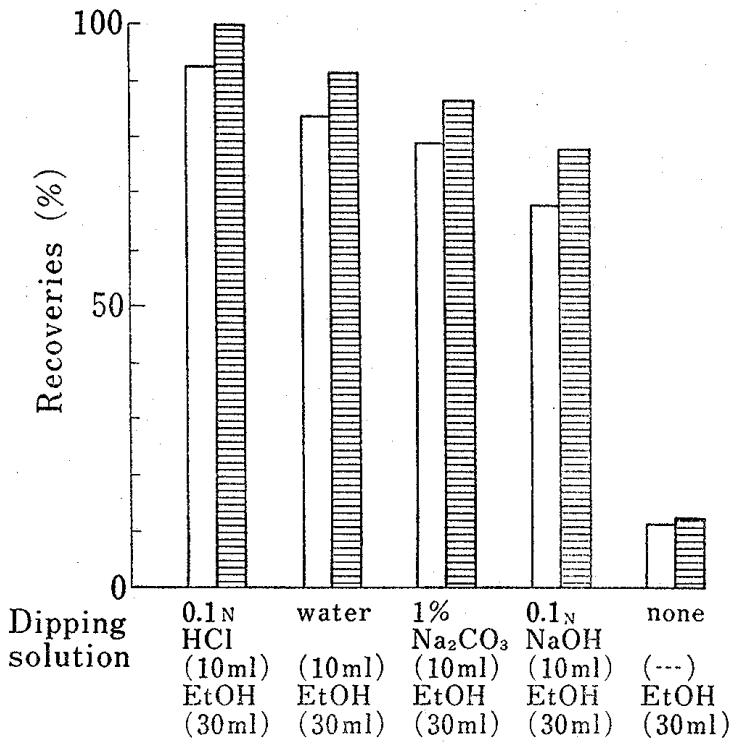

Fig. 3. Recoveries of Benzethonium Chloride from Bamboo Sheath after Dipping in Several Ethanolal Solution

Benzethonium chloride ( $3 \mu$ mole) applied on the reverse side of bamboo sheath was extracted by several ethanolal solution. Steam distilled off ethanol from the extract. Recoveries were obtained from the residual water solution.

$\square$ : dipt for $24 \mathrm{hr} \equiv$ : dipt for $48 \mathrm{hr}$

ノールでいまいちど10分間振とら抽出した。抽出液を合 わせ，水 $60 \mathrm{ml}$ を加えて前項にのベた方法でエタノール 留去を行ない，回收率を求めた結果は約 10\% (Fig. 3) であった.エタノールのみで長時間浸漬してもよい抽出 の効率はえられないことがわかった。

一方，アルカロイドのような塩基性物質の抽出には， しばしば弱アルカリまたは酸性アルコール溶液が用いら れ6)ている. そこで $0.1 \mathrm{~N}$ 塩酸， $0.1 \mathrm{~N}$ 水酸化ナトリウ ムおよび $1 \%$ 炭酸ナトリウム溶液のそれぞれ $10 \mathrm{ml}$ を含 むエタノール溶液 $(40 \mathrm{ml})$ による抽出を試みた。

どの溶液を用いた場合も，Fig. 3に示すように，24時 間よりは48時間浸漬した方がよい回収率が党られた。 た回収率は塩酸酸性溶液による場合がもっとも秀れ，つ いで水， $1 \%$ 炭酸ナトリウム招よび $0.1 \mathrm{~N}$ 水酸化ナトリ ウム溶液の順であった。なかでも, 塩酸溶液に48時間浸 漬すると添ぼ定量的に回収されることがわかった。

QACは食品成分と結合する゙こことが知られているが， 竹の皮の成分と Bとの間にも弱い結合が存在するとみら れ，そのため QACをイオン化して結合を切断しやすく する含水エタノールでは抽出が容易であるが，エタノ一
TABLE III. Recoveries of $B^{a}$ from Reverse Side of Bamboo Sheath after Heating with $0.1 \mathrm{~N} \mathrm{HCl}$

\begin{tabular}{ccl}
\hline $\begin{array}{c}\text { Heating time } \\
(\mathrm{min})\end{array}$ & $\begin{array}{c}\text { Recovery } \\
(\%)\end{array}$ & $\begin{array}{l}\text { Separation of color } \\
\text { developed } \mathrm{DE}^{b)} \text { layer }\end{array}$ \\
\hline 10 & 81.62 & $\begin{array}{l}\text { good } \\
\text { difficult, it should } \\
\text { be centrifuged } \\
20\end{array}$ \\
64.86 & good \\
\hline
\end{tabular}

Small pieces of bamboo sheath $(10 \times 10 \mathrm{~cm})$ after application of $\mathrm{B}(3 \mu \mathrm{mole})$, were heated with $10 \mathrm{ml}$ of $0.1 \mathrm{~N}$ $\mathrm{HCl}$. Extracted with two portions of $30 \mathrm{ml}$ EtOH.

EtOH was steam distilled off. Recoveries were obtained from the residual in the distillating flask.

a) benzethonium chloride

b) 1,2-dichloroethane

ルのみではそれが困難であると推定される。

さらに塩酸溶液中の $\mathrm{QAC} の\left(-\mathrm{N}^{+}-\right) \mathrm{Cl}$ 塩とアルカリ 溶液中の遊離 $\left(-\mathrm{N}^{+}-\right)$との違いが回収率に影響している 之考光られる。すなわら遊離 $\left(-\mathrm{N}^{+}-\right)$住ある程度竹の皮 の陰イオン成分に吸着されるため，アルカリ溶液によっ ては低い回取率がえられたと推定される。

ひきつづきより迅速に抽出を行らため, 還流冷却器を 付したフラスコに試料と塩酸エタノール溶液 $(40 \mathrm{ml})$ を 入れて直火で加熱することを試みた。この操作によって 竹の皮への水分漫透が促進され, 成分との結合切断も速 やかになると考兄られる。加熱時に絨維状物質が竹の皮 から遊離したことるこのことを支持している。

加熱放冷したのち，30 $\mathrm{ml}$ ずつのエタノールで2回よ く振りまぜて抽出し，エタノールを水蒸気蒸留で留去し てえた検液に拈ける回收率は，Table IIIに示すように， 10，20执よび30分間加熱したときそれぞれ81.62，64.86 および102.43\%であった。

20分間加熱したときの低い回収率は先述の繊維状物質 によってもたらされたゲル形成に由来すると推定され， 発色した DE 層を遠心分離しても回収率の改善はみられ なかった。しかし30分間加熱したところ，纎維状物質の 変性のためか。 DE 層の分離は容易となり，回収率もほぼ 定量的な值となった。

したがって，この操作にはクリンアップを迫加する必 要はない、またBのよらに安定な化合物》はこの操作で 分解されない。

\section{4. 竹の皮の表怘よ゙䧶からの QAC の㨨出}

竹の皮の表际よび裹からのB の回取率は, Table IV に示すよらに，1.0-5.0 $\mu$ mole の範囲内でほ漂定量的

6）小竹艎二雄, “新版有機化学," 理工学出版社, 東京, 1951, p. 1484 .

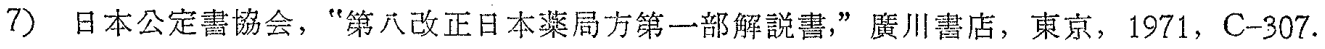


TABLE IV. Recoveries of $\mathrm{B}^{a}$ from Fortified Bamboo Sheath

\begin{tabular}{ccc}
\hline \hline $\begin{array}{c}\text { Applied } \\
(\mu \text { mole })\end{array}$ & \multicolumn{2}{c}{ Recovery $(\%)^{b)}$} \\
\cline { 2 - 3 } & Right side & Reverse side \\
\hline 1.0 & 93.15 & 109.15 \\
3.0 & 101.35 & 101.35 \\
5.0 & 99.71 & 99.13 \\
\hline
\end{tabular}

a) benzethonium chloride

b) Mean value of three trials. Method used was shown in Table III. Minimum detectable were $0.1 \mu$ mole $(44.8 \mu \mathrm{g})$ of benzethonium chloride per $200 \mathrm{~cm}^{2}$ of bamboo sheath.

であった。使用した検討試料は Table III の実験と同様 にして作製した。

\section{5. 市歌竹皮の QAC}

大阪市内で購入した検体 5 件のらち 1 件に，Bとして
$0.2 \mu \mathrm{mole}(89.6 \mu \mathrm{g}) / 200 \mathrm{~cm}^{2}$ の QAC が見出された。他 の4件には QAC は認められなかった。

要

約

つや出しの目的で竹の皮に塗布された QAC は竹の皮 の成分と結合するため抽出が困難であった。塩酸エタノ 一ル溶液で加熱するとその結合は容易に切断されること がわかった。また BPB 比色法による QAC の定量は共 存エタノールで妨害されるのでェタノールの除去につい て検討した結果, 水蒸気蒸留法で留去するのがよいこと がわかった。

以上の結果を綜合して，竹の皮に塗布された QAC の 簢便なスクリーニング法を確立した。

市販品 5 件について調べたところ，1件に QAC を検 出した。

謝辞実験の一部を担当して下さった松本陽子氏に 感謝する。 